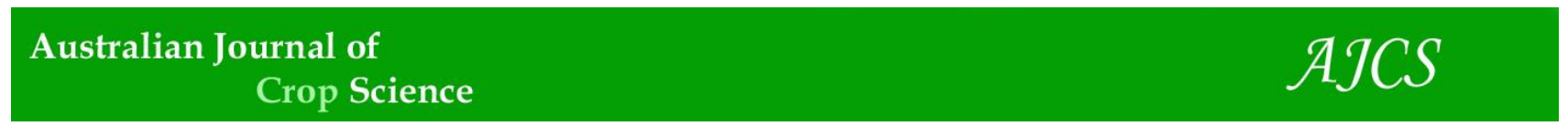

AJCS 15(12):1446-1451 (2021)

ISSN:1835-2707

doi: $10.21475 / a j c s .21 \cdot 15 \cdot 12 . p 3313$

\title{
Production of round wood from planted forests and price of pulp and paper and other forestry purposes in southern Brazil
}

\author{
Gustavo Silva Oliveira*1 ${ }^{1}$, Romano Timofeiczyk Junior ${ }^{1}$, Ailson Augusto Loper ${ }^{1}$, Pedro José Steiner Neto ${ }^{1}$, \\ Ricardo Ribeiro Alves ${ }^{2}$
}

\author{
${ }^{1}$ Department of Rural Economy and Extension, Federal University of Paraná - UFPR, Curitiba, Paraná, Brazil \\ ${ }^{2}$ Department of Forest Engineering, Federal University of Pampa - UNIPAMPA, São Gabriel - Rio Grande do Sul, \\ Brazil $^{2}$
}

*Corresponding author: gustavo_ccp@hotmail.com

\begin{abstract}
The aim of the study is to analyze the production of round wood from planted forests and the price of pulp and paper and other forestry purposes in southern Brazil, from 2000 to 2019. In this study, we worked with historical series from secondary data collected from the Brazilian Institute of Geography and Statistics IBGE, referring to the produced and traded quantity in forestry $\left(\mathrm{m}^{3}\right)$, forestry production value (one thousand dollars) and price $\left(\$ / \mathrm{m}^{3}\right)$, obtained through the ratio between the production value and the respective produced quantities in each year. The silviculture production value (PV) is a derived variable calculated by the weighted average of quantity and average current price paid to the producer $\left(\mathrm{m}^{3}\right)$, according to the harvest and commercialization periods of each product. The price evolution $(P)$ was separated according to purpose and obtained through the quotient between the production value and respective quantities produced in each year. The trend models were estimated, in which annual growth rates of the real price and produced quantity were calculated for the two roundwood purposes in the evaluated period. Then, we sought to fit the results according to the possibilities of shift of the supply and demand curves. The results indicate that pulp and paper presented positive rates of produced quantity and price, of 5.8775 and 1.3704 , respectively. The nomenclature for other purposes had a positive rate for the produced quantity (4.1929) and a negative rate for price $(-0.3203)$. Thus, logwood for pulp and paper showed a dominant shift in the demand curve to the right, showing a rising market, while for other purposes, there was a dominant shift in supply to the right, corroborating the concept of positive variation in quantity and a negative variation in price. Given these results, it is important to highlight that the study refers to one federative unit in Brazil, which signals the recommendation that other similar studies be carried out in other states to better understand the impact of production and price of these purposes on the Brazilian market.
\end{abstract}

Keywords: Forest industry; Demand; Offer; Market.

Introduction

The planted forest sector in Brazil has reached great prominence worldwide over the last decades, due to the positive transformations in relation to development, wealth generation and mitigation of climate changes in the provision of ecosystem services. In 2019, the total area of planted forests in the country added up to 9.0 million hectares, $77 \%$ of which is represented by eucalyptus, with 6.97 million hectares, and $18 \%$ of pine, with 1.64 million hectares (IBA, 2020).

Such representation is mainly due to the rapid growth of these types of forests, in addition to positive competitive advantages related to favorable edaphoclimatic conditions and the national productive capacity. Thus, due to the productive development of forestry companies and the development of the sector's production chain, Brazil has become one of the largest exporters in the international market.

In the southern region of Brazil, this scenario is even more relevant because the wood industry is inserted in production complexes based on pine and eucalyptus planted forests
(Simioni et al., 2015). In this context, in relation to the economic aspects of the sector, the wood industry has a strong influence on the country's economic indicators and strategies Cieslak et al., (2020); Araujo et al., (2017).

The sector's relevance to the Brazilian economy, in terms of income generation, employment generation, taxes and development, has been proven in several scientific studies, such as those by Valverde (2000); Silva (2004); Valverde et al. (2005); Sousa et al. (2010); Martins et al. (2011); Ribaski (2018) and Aquino et al. (2020).

Among the regional highlights, the State of Paraná was responsible for a 30 million $\mathrm{m}^{3}$ production, totalizing $22.9 \%$ of the national production of planted forests in 2019. This scenario corroborates the state's forest productivity to be one of the biggest productions worldwide, comprising the pine and eucalyptus genera, with an average annual increase (IMA) of 34.51 and $43.81 \mathrm{~m}^{3}$ / ha / year, respectively (APRE, 2020).

Furthermore, roundwood from these forests supplies the forest productive chain, being classified according to the 
different assortments and diameter classes, to its use or industrial processing - which can be pulp and paper, furniture, construction industry, among others. In addition, this raw material can go through different processing until it gets to the final consumer, that can be from different segments.

In addition, relevant changes have been taking place in the consumer market for forest products, due to the emergence of new niches and the consolidation of reforestation wood. Thus, forestry industries, such as pulp and paper, steelyards, sawmills, furniture industries, significantly increased their production capacities and production methodologies to meet these demands.

Faced with this scenario, it is essential to analyze market behavior and evolution, understanding the behavior of the forest industries over the years, to find alternatives focused on the growth of the sector and to reconcile the growth rate of industrial production with the reforested areas in the country.

Therefore, the present study aimed to analyze the production of round wood from planted forests and the price of pulp and paper and other forestry purposes in southern Brazil, from 2000 to 2019.

\section{Results and Discussions}

The trends of the variables of interest over the years for roundwood destined for pulp and paper, are shown in Figure 1.

It is noticeable that from 2000 to 2008 the produced quantity showed a continuous growth with small decrease oscillations. In 2009, it slightly decreased again, reflecting the financial crisis of 2008, a period in which the markets declined and became more volatile. The linear growth trend of the produced quantity is caused by the accelerated growth of pulp exports, even after the crisis. Prices, on the other hand, showed a general downward trend after 2005, with a moderate recovery starting on 2016. According to Bacha (2019), production capacity and demand occur through inventory changes, which reflect variations in the prices of these products, in another words, in situations where demand is below production capacity, inventories increase and price drops.

According to IBA (2020), in 2019 there was a 6.6\% reduction in pulp production in Brazil. It possibly happened due to an industry strategy to adjust inventories. In addition, consumption in the domestic market in the same year has declined by $15.4 \%$, reaching 5.5 million tons. This scenario confirms the discussions that demand exceeds production capacity causing inventory reduction, consequently causing an increase in prices.

Over the last decade, there has been a considerable expansion of pulp production capacity in Brazil, with the objective of serving the foreign market since domestic consumption has stabilized.

Although the replacement of paper by technology is noticeable, the segment has adapted and presented growth over the years. The reduction in consumption is directly associated with paper for printing and writing. However, the demand for paper for sanitary and packaging purposes has corroborated the increase in produced quantity, which is proportional to populational growth.

As explained by Sperotto (2014), the impacts of globalization and restructuring in the first half of the 1990s triggered a difficult period for the sector. However, from the 2000s on, with the resumption of pulp and different types of paper prices, the segment regrew Mendonça, (2003).

Figure 2 shows the evolution of roundwood for other purposes, with the respective linear trends of the variables under study.

The quantity of roundwood produced for other purposes had a linear growth trend over the evaluated period. In the same way as the destination for pulp and paper, other purposes were also impacted by the 2008 crisis, having had a great recovery after this period.

It is also worth noting that the demands projection is directly related to product classes, which present different realities according to the diameter of the logs. The demand projection for wood in Paraná is based on variations in historical growth rates of the industrial sectors of the wood production chain. Such accession is justified by the updating of the state legislation based on the new forest code, which makes up different financing conditions for the industries in Paraná.

Considering roundwood price variations for other purposes, planning becomes more difficult, because the consumption of industries is often incompatible with the availability of forest plantations. According to Tomaselli, (2020) with the crisis that started in 2014, and the decrease in GDP (Gross Domestic Product) for three consecutive years, the national forestry industry sought an alternative in the international market. However, there was a reduction in the international demand for forest products, which resulted in price drops. In this context, Mankiw (2019) points out that there are many variables that impact the demand and supply of a product, such as price, income, production costs, technology, and others.

Table 1 shows the growth rates calculated over the period of 2000 to 2019 for the produced quantity and price of roundwood for pulp and paper and other purposes.

The roundwood classification for pulp and paper showed a positive variation in quantity and price, showing a dominant shift in the demand curve to the right. Almeida et al., (2009b) found this type of framework for some non-wood forest products such as açai, mangaba, pequi and piassava, from 1982 to 2005. On the other hand, roundwood for other purposes showed a positive variation in quantity and a negative variation in price, contributing to the interpretation that there was a dominant shift in supply to the right. A similar result was verified by Salles et al., (2016) who evaluated the dynamics of prices and exported quantities of Brazilian forest products, in the period of 1995-2013 and found a dominant shift of supply to the right for wooden panels. When Oliveira et al., (2019) analyzed the displacement of the Brazilian MDF supply in the period from 2008 to 2017, a dominant displacement of the supply to the right was verified, motivated by the market penetration of the national MDF due to the significant price reduction vis-àvis international competitors due to the exchange rate. Usually, the increase in the supply of a certain good is related to a drop in production costs or to an improvement in the technological process and, consequently, an increase in its production, however, other factors can lead to a shift of the supply curve to the right.

\section{Materials and Methods}

\section{Data source}

This work was carried out from secondary data collected from the Brazilian Institute of Geography and Statistics IBGE, 
Table 1. Change rate in the produced quantity and price of roundwood for pulp and paper and other purposes.

\begin{tabular}{|llll|}
\hline Purpose & Growth rate (\%) & Price & Type of framework \\
\cline { 2 - 4 } & Produced quantity & 1.3704 & $\uparrow D$ \\
\hline Pulp and paper & 5.8775 & -0.3203 & $\uparrow O$ \\
\hline Other purposes & 4.1929 & & \\
\hline
\end{tabular}

Source: Authors, 2021.

18.000 .000

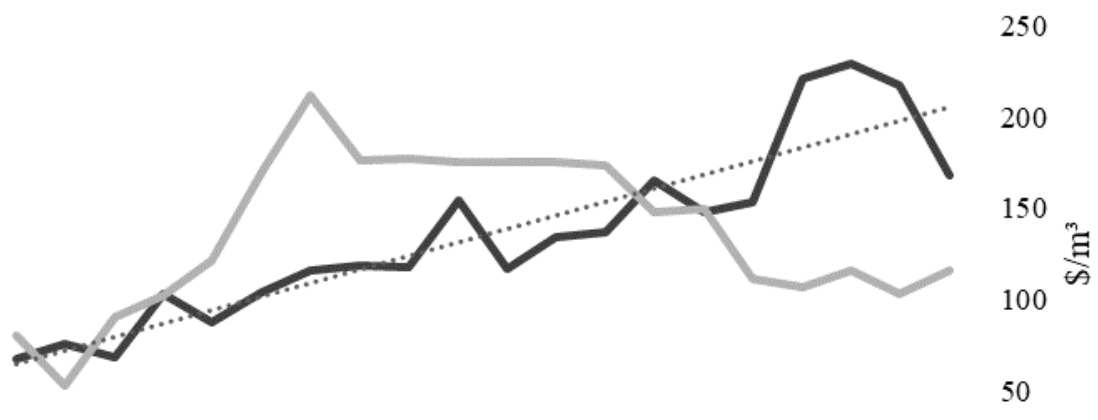

2.000 .000

0

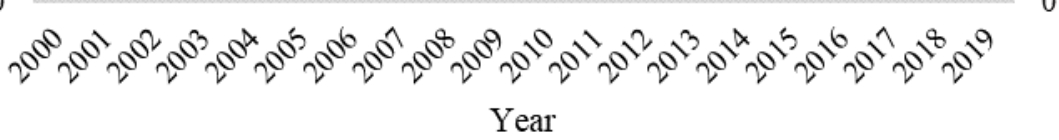

16.000 .000

14.000 .000

12.000 .000

= 10.000 .000

8.000 .000

6.000 .000

4.000 .000

50

0

Year

Produced Quantity $\mathrm{m}^{3}$

Price $\$ / \mathrm{m}^{3}$

Linear (Produced Quantity $\mathrm{m}^{3}$ )

Figure 1: Behavior of quantity and price of roundwood for pulp and paper and its respective linear trends between 2000 and 2019 in the state of Paraná. Source: Authors, 2021.

Table 2. Relation of the shifts in the supply and demand curves according to the signs of growth rates of quantity produced and price.

\begin{tabular}{|lll|}
\hline Type of Framework & $\begin{array}{l}\text { Growth rates directions of produced quantity } \\
\text { and price }\end{array}$ & Variations in demand and supply curves \\
\hline$\uparrow D$ & Positive variation in quantity and price & Dominant shift of demand to the right \\
\hline$\downarrow D$ & $\begin{array}{l}\text { Negative variation in quantity and price } \\
\text { Positive variation in quantity and negative } \\
\text { variation in price }\end{array}$ & \begin{tabular}{l} 
Dominant shift of demand to the left \\
\hline Dominant shift of supply to the right
\end{tabular} \\
\hline$\downarrow O$ & $\begin{array}{l}\text { Negative variation in quantity and positive } \\
\text { variation in price }\end{array}$ & Dominant shift of supply to the left \\
\hline
\end{tabular}

Source: Adapted from Almeida et al. (2009).

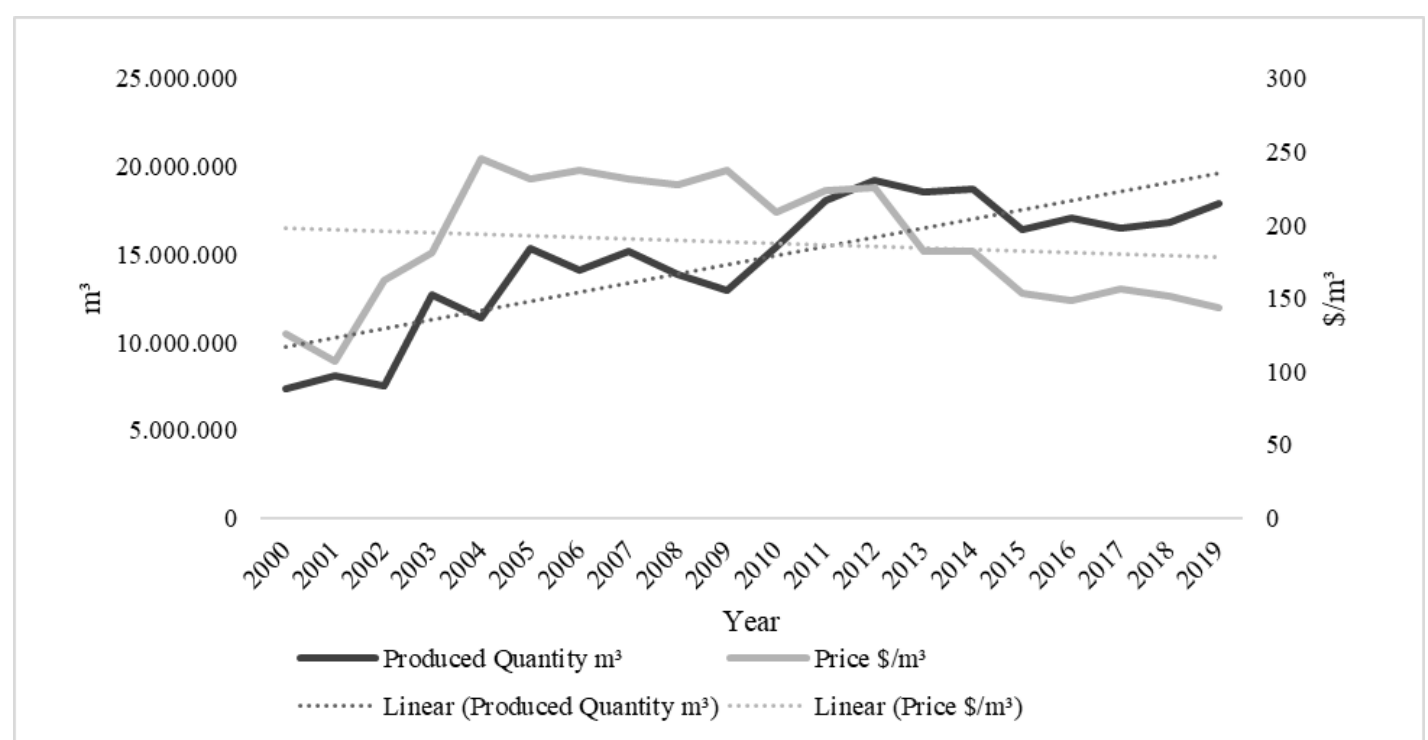

Figure 2: Evolution of quantity and price of roundwood for other purposes and their respective linear trends between 2000 and 2019 in the state of Paraná. Source: Authors, 2021. 

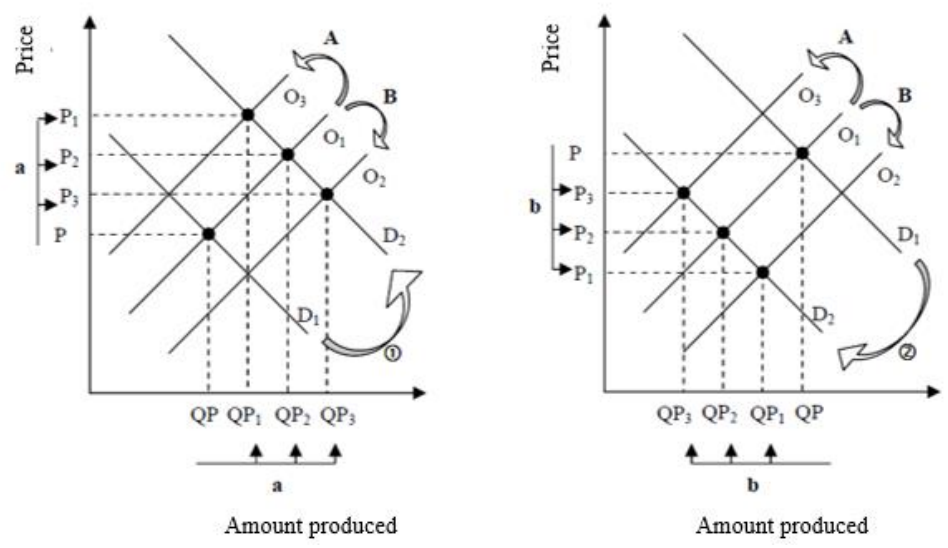

Figure 3. Market behavior considering a dominant shift of supply to the right and to the left, considering the variables of produced quantity and price. Source Adapted from Almeida et al. (2009).
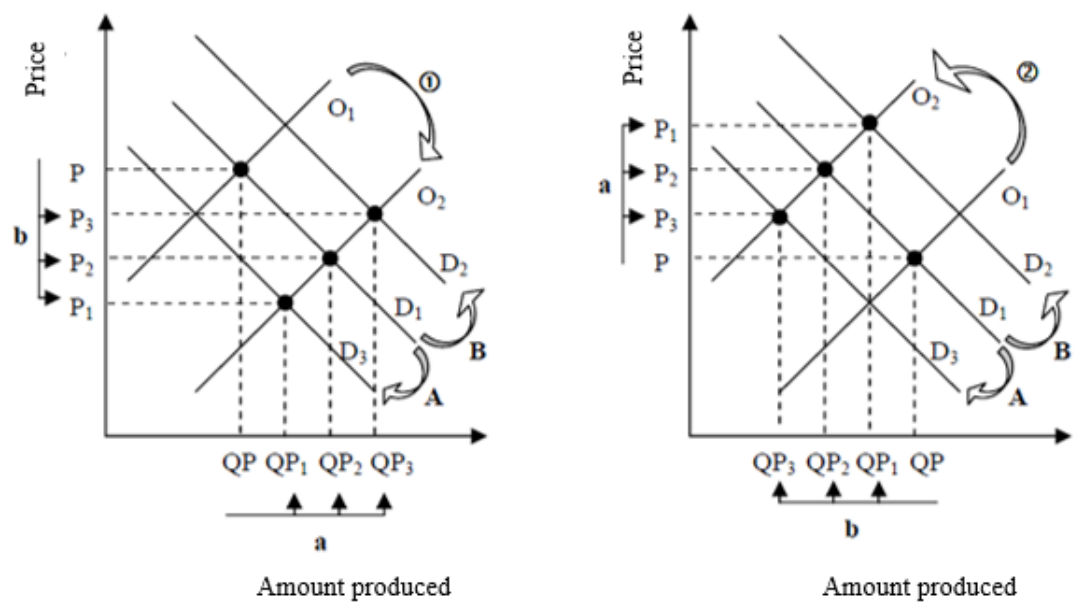

Figure 4: Market behavior considering a dominant shift of supply to the right and to the left, considering the variables of quantity produced according to price. Source Adapted from Almeida et al. (2009).

which were aggregated for Brazil. This institute is recognized as the main data and information provider in the country, serving the needs of the most diverse segments of civil society, as well as federal, state, and municipal government agencies.

Thus, we worked with historical series referring to the produced and traded quantity in silviculture $\left(\mathrm{m}^{3}\right)$ and production value in silviculture (Thousand reais) in the State of Paraná, between the years of 2000 and 2019. The nomenclatures were presented by the IBGE statistics Vegetable Extraction and Silviculture Production (2021) using Eucalyptus, Pine and other species and purposes such as roundwood for pulp and paper and roundwood for other purposes.

Among these forest products are cellulose pulp obtained by the sulfate process (KRAFT), soda, or sulfite and soluble cellulose and paper for printing, cardboard, paper for industry, and others. The other purposes of roundwood are represented by wood panels, sawn wood, and others.

\section{Data analysis and processing}

The production value in silviculture (PV) is a derived variable calculated by the weighted average of quantity and average current price paid to the producer $\left(\mathrm{m}^{3}\right)$, according to the harvest and commercialization periods of each product. Freight charges, fees and taxes are not included in the price. The price evolution $(P)$ was separated according to purpose and obtained through the quotient between the production value and its respective quantities produced in each year (Equation 1).

$P=\frac{P V}{P Q} \quad$ (1)

Where: $P=$ price $\left(\$ / \mathrm{m}^{3}\right) ; P V=$ production value $(\$) ; P Q=$ produced quantity $\left(\mathrm{m}^{3}\right)$.

Prices were deflated by the Broad Consumer Price Index IPCA, September 2000 base, index published by IBGE Research Directorate, price index coordination (NATIONAL CONSUMER PRICE INDEX SYSTEM, 2021).

The trend models were estimated with annual growth rates of the real price and produced quantity calculated for the two roundwood purposes in the evaluated period.

Then, we aimed to fit the results according to the possibilities of shift of the supply and demand curves. To this end, the methodology adapted from Gujarati (2000) was applied in order to obtain the estimates of annual growth rates for the price and produced quantity through Equation 2.

$Y_{t}=Y_{0}(1+r)^{t}(2)$

Where: $Y t=$ price or quantity considering the rate " $r$ " over time $t$; $\mathrm{YO}=$ initial price or quantity; $r=$ compound rate; $t=$ Period

Then, the natural logarithm (In) was calculated, which makes it possible to study phenomena that evolve exponentially, 
and the perturbation term $\varepsilon \mathrm{t}$ was added, according to Equations 2 and 3.

$$
\begin{aligned}
& \ln Y_{t}=\ln Y_{0}+t \ln (1+r)(2) \\
& \ln Y_{\mathrm{t}}=\beta_{1}+\beta_{2} t+\varepsilon_{t}
\end{aligned}
$$

Where: $\beta 1=\ln Y 0$ e $\beta 2=\ln (1+r)$.

For the verification of the growth rate (\%) in $Y$ in the period from 2000 to 2019, the Equation 2 antilog was calculated, then subtracted by 1 and its product divided by 100 .

Based on the signs of the calculated growth rates, market behavior and factors related to supply and demand curves were determined. The determination of a dominant shift in demand was made as described in Figure 3.

Based on this behavior, an increase (a) or decrease (b) in the price and quantity of produced roundwood, not considering a shift of the supply curve to the left (A) or right (B), triggers a shift of the demand curve to the right (1) or left (2). The relation of the dominant shifts of the supply curve can be verified in Figure 4.

When the dominant shift of the supply curve is analyzed, consequently it causes a reversion in the direction of the quantity and price. In this scenario, an increase in supply to the right (1) greater than any shift in demand, be it to the left or right ( $A$ or $B$ ), there is an increase in the produced quantity and a decrease in price. Therefore, dominant supply accessions to the left (2), cause an increase in price and a decrease in quantity.

Subsequently, having obtained the growth rate results, the reaction of the roundwood market was determined, in relation to the demand and supply curves according to the classification proposed by Almeida et al., (2009a) according to Table 2.

The variables of price or produced quantity were considered to favor exposure of the results, the possible directions of the growth rates were related to the dominance and direction of the shifts in the supply or demand curves.

\section{Conclusions}

Based on the introduced results, it was concluded that the roundwood presented different behaviors when the two purposes under study were compared and presented few restrictions in market evolution.

In the case of pulp and paper, the results generally showed a market scenario on the rise with a dominant framework of demand to the right and, consequently, a positive variation in the commercialized quantity and in the price for the analyzed period, corroborating the state's competitive potential in meeting internal and external demands.

Regarding roundwood for other purposes, an increase in the produced quantity is presented, however, with a drop in its price, so in the analyzed period, a dominant shift to the right in the supply of these products was observed.

Given these results, it is worth noting that the study refers to one federative unit in Brazil, which signals the recommendation that other similar studies be carried out in other states to better understand the impact of production and the price of these purposes on the Brazilian market.

\section{Acknowledgements}

This work was developed with financial support from the Coordination of Improvement of Higher Education Personnel (CAPES) - Financing Code 001.

\section{References}

Almeida AN de, Humberto A, Silva JCGL da, Hoeflich VA (2010) Mercado de madeiras tropicais: substituição na demanda de exportação. Acta Amazônica, 40(1): 119-126. DOI: 10.1590/S0044-59672010000100015.

Almeida AN de, Santos AJ, Silva JCGL da, Bittencourt AM (2009a) Evolução da produção e preço dos principais produtos florestais não madeireiros extrativos do Brasil. Cerne, 15(3): 282-287.

Almeida AN de, Santos AJ, Silva JCGL da, Bittencourt AM (2009b) Evolução da produção e preço dos principais produtos florestais não madeireiros extrativos do Brasil. Cerne. 15(3): 282-287.

Aquino MGC, Silva JJN, Pacheco Neto G, Oliveira LB, Soares PRC (2020) Análise de SWOT do setor florestal na região serrana do estado de Santa Catarina. Natural Resources. 10(2): 68-75.

Araujo VD, Garcia JN, Barbosa JC, Christofor AL (2017) Importância da Madeira de Florestas Plantadas para a Indústria de Manufaturados, Pesquisa Florestal Brasileira 37(90): 189-200.

Associação Paranaense de Empresas de Base Florestal APRE. Estudo setorial 2020. Available in: https://apreflorestas.com.br/publicacoes/estudo-setorialapre-2020-2/. Access in: 29 jan. 2021.

Gujarati DN (2000) Econometria básica. 3. ed., São Paulo: Makron Books, 846.

Cieslak M, Mikuska R, Dal Santos AS, Gonzaga CAM (2020). Os desafios das ações sustentáveis na indústria madeireira: o caso da sps tecnologia ambiental LTDA. Reves - Revista Relações Sociais, 3(1), 0062-0075.

Indústria Brasileira de Árvores. Relatório IBA 2020. Available in:

https://iba.org/datafiles/publicacoes/relatorios/relatorioiba-2020.pdf. Access in: 20 jan 2020.

Instituo Brasileiro de Geografia E Estatística (IBGE). Produção da Extração Vegetal e da Silvicultura. Available in: https://sidra.ibge.gov.br/home/ipp/brasil. 2021. Access in: 20 jan. 2021.

Mankiw NG (2019) Introdução à economia. São Paulo: Cengage Learning, 852.

Mankiw NG (2001) Introdução à Economia: princípios de micro e macroeconomia. 2. ed. Rio de Janeiro: Elsevier, 872.

Martins G, Corso NM, Kureski R, Hosokawa RT, Rochadelli R (2001) Inserção do setor florestal na estrutura econômica do Paraná. Revista Paranaense de Desenvolvimento, 104: 5-21.

Mendonça M (2003) El complejo forestal en Brasil. In: Bercovich N, Katz J. (Org.). El desarrollo de complejos forestales en América Latina. Bogotá: CEPAL, 83-121.

Oliveira DV, Noce R, Oliveira JM, Lobato LFL, Leal SR, Rocha JS (2019) Deslocamento da oferta do MDF brasileiro no período de 2008-2017. Revista Ibero Americana de Ciências Ambientais, 10(3): 1-7.

Ribaski NG (2018) Conhecendo o setor florestal e perspectivas para o futuro. Brazilian Journal of Animal and Environmental Research, Curitiba, 1(1): 44-58. 
Salles TT, Isbaex C da, Silva ML, Valverde SR, Luz TMO (2016) Dinâmica de preços e quantidades exportadas de produtos florestais brasileiros, 1995-2013. Pesquisa Florestal Brasileira, 36(88): 451-457.

Silva LMS (2004) Relações intersetoriais da economia acreana e sua inserção na economia brasileira: uma análise insumo-produto. Economia Aplicada - Escola Superior de Agricultura "Luiz de Queiroz", Piracicaba, 168.

Simioni FJ, Hoff DN, Binotto E (2015) Inducing Factors for Technological Innovation of the Wood Industry in the Region of Lages/SC. Revista de Administração e Inovação, 12(1): 248-270

Sistema Nacional de Índices de Preços Ao Consumidor SNIPC. Índice Nacional de Preços ao Consumidor Amplo IPCA. Available

in: https://www.ibge.gov.br/estatisticas/economicas/precose-custos/9256-indice-nacional-de-precos-ao-consumidoramplo.html?=\&t=o-que-e . 2021. Access in: 20 jan. 2021.

Sousa EP, Soares NS, Silva ML, da, Valverde SR (2010) Desempenho do setor florestal para a economia brasileira: uma abordagem da Matriz Insumo-Produto. Revista Árvore, 34(6): 1129-1138.

Sperotto FQ (2014) A expansão do setor de celulose de mercado no Brasil: condicionantes e perspectivas. Indicadores Econômicos FEE, Porto Alegre, 41(4): 85-100.

Tomaselli I (2015) Evolução recente do mercado internacional de produtos florestais e a indústria nacional. Revista Referência florestal. Disponível em: https://www.stcp.com.br/wpcontent/uploads/2020/02/Florestal_215_Ivan_Tomaselli.p df. Acesso em: 29 jan. 2021.

Valverde SRA (2000) Contribuição do setor florestal para o desenvolvimento socioeconômico: uma aplicação de modelos de equilíbrio multissetoriais. Tese (Doutorado em Ciência Florestal) - Universidade Federal de Viçosa, Viçosa, 105.

Valverde SR, Oliveira GG de, Carvalho RMAM, Soares TS (2005) Efeitos multiplicadores do setor florestal na economia capixaba. Revista Árvore, 29(1): 85-93. 